\title{
Synthesis of Magnesium Silicon Nitride by the Nitridation of Powders in the Magnesium-Silicon System
}

\author{
Hiroshi UCHIDA, Kiyoshi ITATANI, Mamoru AIZAWA, F. Scott HOWELL and Akira KISHIOKA \\ Department of Chemistry, Faculty of Science and Engineering, Sophia University, 7-1, Kioi-cho, Chiyoda-ku, Tokyo 102 \\ マグネシウムーケイ素系粉体の窒化による窒化ケイ素マグネシウムの合成 \\ 内田 寛・板谷清司・相澤 守 F. Scott Howell ・岸岡 昭 \\ 上智大学理工学部化学科, 102 東京都千代田区紀尾井町 7-1
}

\begin{abstract}
Magnesium silicon nitride $\left(\mathrm{MgSiN}_{2}\right)$ was synthesized by the nitridation of powders in the magnesium (Mg)silicon ( $\mathrm{Si}$ ) system. Although an $\mathrm{Mg}$ and $\mathrm{Si}$ powder with an $\mathrm{Mg} / \mathrm{Si}$ ratio of 1.0 (= stoichiometric ratio of $\mathrm{MgSiN}_{2}$ ) was heated up to $1400^{\circ} \mathrm{C}$ in nitrogen $\left(\mathrm{N}_{2}\right)$, a single phase of $\mathrm{MgSiN}_{2}$ could not be obtained, due to evaporation of $\mathrm{Mg}$ during heating. On the basis of the information that $\mathrm{Mg}_{2} \mathrm{Si}$ formed as an intermediate phase during the synthesis of $\mathrm{MgSiN}_{2}$, an $\mathrm{Mg}_{2} \mathrm{Si}$ powder was heated at a temperature between 600 and $1600^{\circ} \mathrm{C}$ for $1 \mathrm{~h}$ in $\mathrm{N}_{2}$. Although $\mathrm{MgSiN}_{2}$ and other phases such as $\mathrm{Si}$ and amorphous $\mathrm{Mg}_{3} \mathrm{~N}_{2}$ were present in the temperature range of $900^{\circ} \mathrm{C}$ to $1300^{\circ} \mathrm{C}$, the powder heated at $1400^{\circ} \mathrm{C}$ consisted of only $\mathrm{MgSiN}_{2}$ phase. The chemical composition of the powder heated at $1400^{\circ} \mathrm{C}$ for $1 \mathrm{~h}$ was almost stoichiometric; the content of the oxygen was as low as $0.76 \mathrm{~mol} \%$. The powder consisted of agglomerates with sizes of $\sim 5 \mu \mathrm{m}$; these agglomerates were furthermore composed of primary particles with an average size of $0.54 \mu \mathrm{m}$. The oxidation resistant temperature of $\mathrm{MgSiN}_{2}$ was estimated to be $\sim 830^{\circ} \mathrm{C}$. The $\mathrm{MgSiN}_{2}$ powder had good resistivity to hydration.

[Received March 13, 1997; Accepted August 7, 1997]
\end{abstract}

Key-words : Magnesium silicon nitride, Magnesium, Silicon, Magnesium silicide, Nitridation, Oxygen content, Oxidation-resistant temperature, Hydration resistance

\section{Introduction}

Magnesium silicon nitride $\left(\mathrm{MgSiN}_{2}\right)$ has orthorhombic crystal structure similar to aluminum nitride (A1N) with a high theoretical thermal conductivity of $319 \mathrm{~W} \cdot \mathrm{m}^{-1} \cdot \mathrm{K}^{-1}$. Thus $\mathrm{MgSiN}_{2}$ is expected to be available as electronic substrates/packages, if the thermal conductivity and mechanical strength of $\mathrm{MgSiN}_{2}$ are comparable to those of AlN. ${ }^{2)}$ Groen et al. ${ }^{3)}$ and Hintzen et al., ${ }^{4}$ however, reported that the thermal conductivity of $\mathrm{MgSiN}_{2}$ ceramics is as low as $15-17 \mathrm{~W} \cdot \mathrm{m}^{-1} \cdot \mathrm{K}^{-1}$, regardless of the mechanical properties being sufficient for the practical uses. The poor thermal conductivity of $\mathrm{MgSiN}_{2}$ ceramics is ascribed to the presence of oxygen in the crystal lattice of $\mathrm{MgSiN}_{2} \cdot{ }^{3), 4)}$

Some further research is, therefore, needed to examine the conditions for the synthesis of $\mathrm{MgSiN}_{2}$ with low oxygen content. The $\mathrm{MgSiN}_{2}$ has previously been synthesized by the reaction of magnesium nitride $\left(\mathrm{Mg}_{3} \mathrm{~N}_{2}\right)$ with silicon nitride $\left(\mathrm{Si}_{3} \mathrm{~N}_{4}\right)^{3)-5)}$ and by the nitridation of magnesium silicide $\left(\mathrm{Mg}_{2} \mathrm{Si}\right) .^{5)}$ Nevertheless, no detailed information on the synthesis conditions of $\mathrm{MgSiN}_{2}$ to obtain a pure compound has been available yet.

The present authors previously examined the synthesis conditions of $\mathrm{Mg}_{3} \mathrm{~N}_{2}$ through the low-pressure chemical vapor deposition, i.e., the nitridation of the vaporized $\mathrm{Mg}^{6}$ ) Based on this information, the authors furthermore examined ( $i$ ) the synthesis conditions of $\mathrm{MgSiN}_{2}$ by the nitridation of the powders in the $\mathrm{Mg}-\mathrm{Si}$ system and (ii ) some properties of the resulting powder.

\section{Experimental procedure}

2.1 Starting materials and synthesis of $\mathrm{MgSiN}_{2}$

Two kinds of the starting materials, i.e., (i ) $\mathrm{Mg}$ powder (Wako Pure Chem.; purity, 99.9\%) and (ii) Si powder (Nilako; purity, 99.999\%), were used in this experiment; the particle sizes of $\mathrm{Mg}$ powder determined using a scanning electron microscope (SEM) were in the range of 300 to $500 \mu \mathrm{m}$, whereas those of Si powder were in the range of 10 to $100 \mu \mathrm{m}$. After mixing these powders with the desired
$\mathrm{Mg} / \mathrm{Si}$ ratios, about $0.3 \mathrm{~g}$ of the powder mixture was pressed at $50 \mathrm{MPa}$ to form the compact with a diameter of 10 $\mathrm{mm}$ and a thickness of $\sim 2 \mathrm{~mm}$. The compact was heated up to the desired temperature at the rate of $10^{\circ} \mathrm{C} \cdot \mathrm{min}^{-1}$ in a nitrogen $\left(\mathrm{N}_{2}\right)$ atmosphere and was kept for $1 \mathrm{~h}$. The heattreated compact was pulverized using an agate mortar and pestle.

\subsection{Evaluation of the powder properties}

The crystalline phases of the powder were identified using an X-ray powder diffractometer (XRD; Model RADIIA, Rigaku, Tokyo; $40 \mathrm{kV}, 25 \mathrm{~mA}$ ) with Ni-filtered $\mathrm{Cu} \mathrm{K} \alpha$ radiation. The $\mathrm{Mg}$ and $\mathrm{Si}$ contents were determined using an energy-dispersive X-ray microanalyser (EDX; Model EMAX-5770, Horiba, Kyoto); the oxygen and nitrogen contents were determined using an N/O determinator (Model TC-136, Leco, St. Joseph, MI, USA). The binding energy of $\mathrm{Si}$ was examined using an X-ray photoelectron spectroscope (XPS; Model SSX-100, SSI, Mountain View, CA, USA). The differential thermal analysis (DTA) and thermogravimetry (TG) were conducted using a DTA-TG apparatus (Model 8076D1, Rigaku, Tokyo) at the heating rate of $10^{\circ} \mathrm{C} \cdot \mathrm{min}^{-1}$ in the $\mathrm{N}_{2}$ atmosphere.

The particle shapes of the powders were observed using a high-resolution transmission electron microscope (HRTEM; Model H-9000, Hitachi; accelerating voltage, 300 $\mathrm{kV}$ ) and using scanning electron microscope (SEM, Model $\mathrm{S}-4500$, Hitachi; accelerating voltage, $20 \mathrm{kV}$ ). The specific surface area was measured by a BET technique, using $\mathrm{N}_{2}$ gas as an adsorption gas.

Assuming the primary particles to be spherical, we calculated the average primary particle size $\left(G_{\mathrm{BET}}\right)$ as follows:

$$
G_{\mathrm{BET}}=\frac{6}{\rho s}
$$

where $\rho$ is the true density and $s$ is the specific surface area of the powder. The true density of the powder was measured picnometrically at $25.0^{\circ} \mathrm{C}$. The crystallite size 
$\left(G_{\mathrm{XRD}}\right)$ of $\mathrm{MgSiN}_{2}$ was calculated by X-ray diffractometry on the basis of Scherrer's formula:

$$
G_{\mathrm{XRD}}=\frac{K \lambda}{\beta \cos \theta}
$$

where $K$ is a constant $(=0.9)$ and $\lambda$ is the wavelength $(=0.15405 \mathrm{~nm})$ of $\mathrm{Cu} \mathrm{K} \alpha_{1}, \beta$ is a half-width of a characteristic X-ray reflection (322) and $\theta$ is a Bragg angle.

The water-proof test of the powder was conducted as follows: $1.0 \mathrm{~g}$ of the powder was immersed in $200 \mathrm{~cm}^{3}$ of boiling water for $24 \mathrm{~h}$; the water-immersed powder was dried in an oven at $110^{\circ} \mathrm{C}$. The changes in sample weight were calculated on the basis of the precise measurements of the sample weights before and after immersing the powder in the boiling water.

\section{Results and discussion}

\subsection{Synthesis of MgSiN}

3.1.1 Reaction among $\mathrm{Mg}$, Si and $\mathrm{N}_{2}$

The reaction among $\mathrm{Mg}$, Si and $\mathrm{N}_{2}$ was examined to search for the optimum conditions for the synthesis of $\mathrm{MgSiN}_{2}$. The mixing ratio of $\mathrm{Mg}$ to $\mathrm{Si}$ was adjusted to be 1.0 (=stoichiometric ratio). Details of the synthesis of $\mathrm{MgSiN}_{2}$ by this technique are described below.

First, the reaction process among $\mathrm{Mg}$, Si and $\mathrm{N}_{2}$ during the heating was examined using DTA-TG and XRD. Figure 1 shows the DTA-TG curves of the $\mathrm{Mg}$ and $\mathrm{Si}$ powders with the $\mathrm{Mg} / \mathrm{Si}$ ratio of 1.0 in $\mathrm{N}_{2}$ atmosphere. The DTA-TG curve contained the exothermic effects at $550^{\circ} \mathrm{C}$ and $770^{\circ} \mathrm{C}$. The TG curve showed that the sample weight increased from $550^{\circ} \mathrm{C}$ up to $1000^{\circ} \mathrm{C}$ and became almost constant in the range of $1000^{\circ} \mathrm{C}$ to $1100^{\circ} \mathrm{C}$; the sample weight decreased slightly with a further increase in temperature up to $1400^{\circ} \mathrm{C}$.

On the basis of the above DTA-TG data, the crystalline phases of the heat-treated powders were examined using the XRD. Typical X-ray diffraction patterns of the heat treated powders are shown in Fig. 2, together with the pattern of the as-mixed powder. The crystalline phases of the powder at room temperature were $\mathrm{Mg}$ and $\mathrm{Si}$, whereas those of the powder heated at $700^{\circ} \mathrm{C}$ were $\mathrm{Si}, \mathrm{Mg}_{2} \mathrm{Si},{ }^{7)}$ $\mathrm{Mg}_{3} \mathrm{~N}_{2}{ }^{8)}$ and $\mathrm{MgO}$ (trace). Although $\mathrm{MgSiN}_{2}{ }^{9}$ was detected above $900^{\circ} \mathrm{C}, \mathrm{Si}$ and $\mathrm{MgO}$ were still present in the powder. The powder heated at $1400^{\circ} \mathrm{C}$ contained not only $\mathrm{MgSiN}_{2}$ but also $\alpha-\mathrm{Si}_{3} \mathrm{~N}_{4}$ and $\mathrm{MgO}$; the X-ray intensities of $\mathrm{MgSiN}_{2}$ were higher than those of the powder heated at $900^{\circ} \mathrm{C}$.

Since $\mathrm{Si}, \mathrm{Mg}, \mathrm{Mg}_{2} \mathrm{Si}$ and $\mathrm{Mg}_{3} \mathrm{~N}_{2}$ were detected from the powder heated at $700^{\circ} \mathrm{C}$, the first exothermic effect at $550^{\circ} \mathrm{C}$

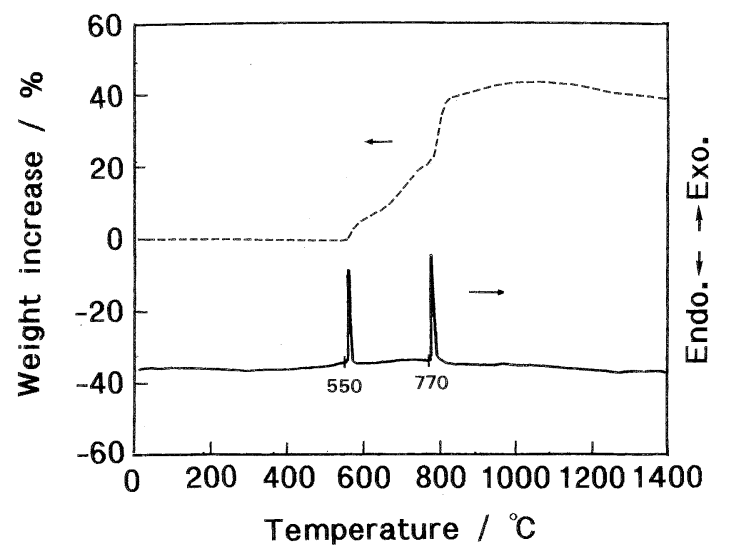

Fig. 1. DTA-TG curve of $\mathrm{Mg}$ and $\mathrm{Si}$ powder with the $\mathrm{Mg} / \mathrm{Si}$ ratio of 1.0 in $\mathrm{N}_{2}$ atmosphere at the heating rate of $10^{\circ} \mathrm{C} \cdot \mathrm{min}^{-1}$.

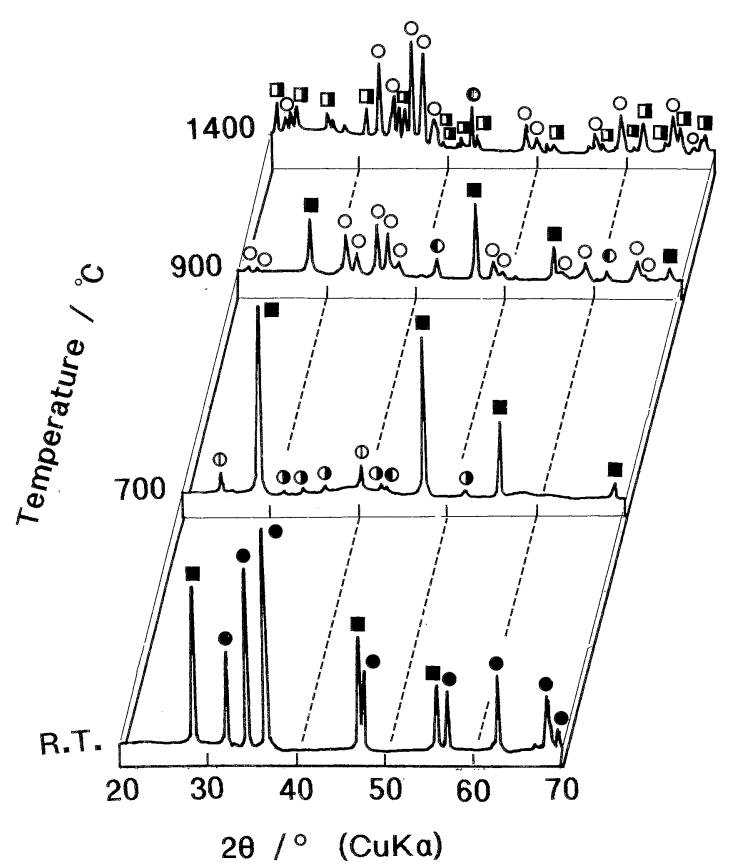

Fig. 2. Typical X-ray diffraction patterns of the $\mathrm{Mg}$ and $\mathrm{Si}$ powder with the $\mathrm{Mg} / \mathrm{Si}$ ratio of 1.0 in $\mathrm{N}_{2}$ atmosphere heated up to the desired temperature at the rate of $10^{\circ} \mathrm{C} \cdot \mathrm{min}^{-1}$.

$\mathrm{Mg}, \mathrm{Si}, \mathrm{Mg}_{3} \mathrm{~N}_{2}, \oplus \mathrm{Mg}_{2} \mathrm{Si}$,

MgO, $\bigcirc \mathrm{MgSiN}_{2}, \mathbb{\alpha} \alpha-\mathrm{Si}_{3} \mathrm{~N}_{4}$.

is attributed to ( $\mathrm{i}$ ) the solid-state reaction between $\mathrm{Mg}$ and $\mathrm{Si}$ (Eq. (3)) and (ii) the solid-gas reaction between $\mathrm{Mg}$ and $\mathrm{N}_{2}$ (Eq. (4))

$2 \mathrm{Mg}+\mathrm{Si} \longrightarrow \mathrm{Mg}_{2} \mathrm{Si}$

$3 \mathrm{Mg}+\mathrm{N}_{2} \longrightarrow \mathrm{Mg}_{3} \mathrm{~N}_{2}$

Although $\mathrm{MgO}$ was present in the powders heated at and above $700^{\circ} \mathrm{C}$, the formation of such oxide may chiefly be derived from the oxygen and/or water $\left(\mathrm{H}_{2} \mathrm{O}\right)$ vapor adsorpted on the surfaces of starting $\mathrm{Mg}$ particles, because $\mathrm{Mg}$ particles are more sensitive to the oxygen and $\mathrm{H}_{2} \mathrm{O}$ vapor than Si particles. ${ }^{10}$ )

Since $\mathrm{MgSiN}_{2}$ was detected at $900^{\circ} \mathrm{C}$, the second exothermic effect at $770^{\circ} \mathrm{C}$ is attributed to the formation of $\mathrm{MgSiN}_{2}$ as follows:

$$
3 \mathrm{Mg}_{2} \mathrm{Si}+4 \mathrm{~N}_{2} \longrightarrow 3 \mathrm{MgSiN}_{2}+\mathrm{Mg}_{3} \mathrm{~N}_{2} \text { (amorphous) }
$$

Although no distinct weight increase occurred in the range of $800^{\circ} \mathrm{C}$ to $1100^{\circ} \mathrm{C}$, this phenomenon may be explained in terms of the balance of the weight increase and decrease, i.e., ( $\mathrm{i}$ ) the weight increase due to the participation of $\mathrm{N}_{2}$ in the formation of $\mathrm{MgSiN}_{2}$ and (ii ) the weight decrease due to the evaporation of $\mathrm{Mg}$ (melting point: $650^{\circ} \mathrm{C}$ ). ${ }^{10)}$ The slight decrease in sample weight with temperature from $1100^{\circ} \mathrm{C}$ to $1400^{\circ} \mathrm{C}$ is attributed to the evaporation and decomposition of amorphous $\mathrm{Mg}_{3} \mathrm{~N}_{2}$ and/or the evaporation of the small amount of the unreacted $\mathrm{Mg}$ above the boiling point $\left(1107^{\circ} \mathrm{C}\right) .{ }^{10)}$ Moreover, although $\alpha-\mathrm{Si}_{3} \mathrm{~N}_{4}$ was detected at $1400^{\circ} \mathrm{C}$, this phenomenon is not ascribed to the decomposition of $\mathrm{MgSiN}_{2}$ but to the nitridation of the residual $\mathrm{Si}$, because the X-ray intensities of $\mathrm{MgSiN}_{2}$ were enhanced with temperature:

$$
3 \mathrm{Si}+2 \mathrm{~N}_{2} \longrightarrow \mathrm{Si}_{3} \mathrm{~N}_{4}
$$

Since the evaporation of $\mathrm{Mg}$ during the heating makes the formation of the single $\mathrm{MgSiN}_{2}$ phase difficult, we furthermore examined the nitridation behavior of $\mathrm{Mg}$ and $\mathrm{Si}$ powder with the $\mathrm{Mg} / \mathrm{Si}$ ratio of 2.0 ; the $\mathrm{Mg}$ content was two times as high as the stoichiometric value. When the $\mathrm{Mg}$ and $\mathrm{Si}$ powder was heated up to $1400^{\circ} \mathrm{C}$, the crystalline 
phases were $\mathrm{MgSiN}, \alpha-\mathrm{Si}_{3} \mathrm{~N}_{4}$ and $\mathrm{MgO}$ (trace). Regardless of an increase of $\mathrm{Mg}$ content in the starting powder, the single $\mathrm{MgSiN}_{2}$ phase could not be obtained. Here the vapor pressure $(P)$ of $\mathrm{Mg}$ in the range of $651^{\circ} \mathrm{C}$ to $1127^{\circ} \mathrm{C}$ can be expressed as follows: ${ }^{11)}$

$$
\log 760 P=-\frac{7610}{T}-1.020 \log T+11.61
$$

where $T$ indicates the absolute temperature. The vapor pressures at $650^{\circ} \mathrm{C}$ (melting point) and $1107^{\circ} \mathrm{C}$ (boiling point) are found from calculation to be $2.9 \times 10^{2} \mathrm{~Pa}$ and $1.0 \times 10^{5} \mathrm{~Pa}$, respectively; the vapor pressure at $1107^{\circ} \mathrm{C}$ is about 350 times as high as that at $650^{\circ} \mathrm{C}$. Such rapid evaporation of $\mathrm{Mg}$ above the boiling point $\left(1107^{\circ} \mathrm{C}\right)$ makes the synthesis of stoichiometric $\mathrm{MgSiN}_{2}$ difficult.

As the present data indicate, we could not find the optimum conditions for the formation of $\mathrm{MgSiN}_{2}$ through the reaction among $\mathrm{Mg}$, Si and $\mathrm{N}_{2}$; the reason may be that $\mathrm{Mg}$ are easily evaporated during heating.

3.1.2 Reaction of $\mathrm{Mg}_{2} \mathrm{Si}$ with $\mathrm{N}_{2}$

We found that $\mathrm{Mg}_{2} \mathrm{Si}$ forms as an intermediate phase during the synthesis of $\mathrm{MgSiN}_{2}$. Based on this information, we furthermore examined the optimum conditions for the synthesis of $\mathrm{MgSiN}_{2}$ by the nitridation of $\mathrm{Mg}_{2} \mathrm{Si}$. Here $\mathrm{Mg}_{2} \mathrm{Si}$ was synthesized by the solid-state and solid-liquid reactions between $\mathrm{Mg}$ and $\mathrm{Si}$; about $0.3 \mathrm{~g}$ of the powder mixture with $\mathrm{Mg} / \mathrm{Si}$ ratio of 2.0 was pressed at $50 \mathrm{MPa}$ and then heated at $700^{\circ} \mathrm{C}$ for $1 \mathrm{~h}$ in $\mathrm{Ar}$ atmosphere.

After the pulverization of the heat-treated compact, the properties of the resulting powder $\left(\mathrm{Mg}_{2} \mathrm{Si}\right)$ were recorded as follows: ( $\mathrm{i}$ ) the color of the powder was pale-gray, (ii) the chemical composition determined using the EDX was: $\mathrm{Mg} 66.50 \mathrm{~mol} \%$, Si $32.96 \mathrm{~mol} \%$ and was almost in accord with the stoichiometric composition; (iii) the oxygen content determined using the $\mathrm{N} / \mathrm{O}$ determinator was 0.64 mol\%; (iv) the specific surface area and primary particle size were $6.8 \mathrm{~m}^{2} \cdot \mathrm{g}^{-1}$ and $0.44 \mu \mathrm{m}$, respectively. The preparation of the $\mathrm{Mg}_{2} \mathrm{Si}$ powder with the stoichiometric composition may be achieved, partly because the vapor pressure of $\mathrm{Mg}$ calculated on the basis of Eq. (7) is still as low as $7.2 \times 10^{2} \mathrm{~Pa}$ at $700^{\circ} \mathrm{C}$, and partly because the reaction products in the $\mathrm{Mg}-\mathrm{Si}$ system, which are formed at the interfaces between $\mathrm{Mg}$ and Si particles during the heating up to $700^{\circ} \mathrm{C}$, prevent $\mathrm{Mg}$ from vaporizing.

Figure 3 shows the DTA-TG curves of $\mathrm{Mg}_{2} \mathrm{Si}$ powder in $\mathrm{N}_{2}$ atmosphere. The DTA curve showed that the exothermic effects started at $800^{\circ} \mathrm{C}$ and $820^{\circ} \mathrm{C}$, whereas the endothermic effect appeared at $1110^{\circ} \mathrm{C}$. The TG curve showed that the sample weight increased remarkably with

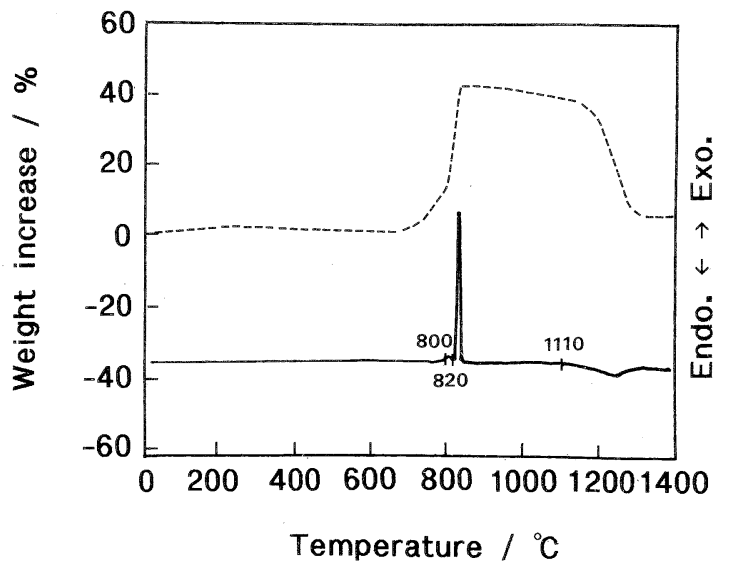

Fig. 3. DTA-TG curve of the $\mathrm{Mg}_{2} \mathrm{Si}$ powder in the $\mathrm{N}_{2}$ atmosphere at the heating rate of $10^{\circ} \mathrm{C} \cdot \mathrm{min}^{-1}$. temperature from $670^{\circ} \mathrm{C}$ up to $820^{\circ} \mathrm{C}$; the sample weight was reduced in the range of $820^{\circ} \mathrm{C}$ to $1320^{\circ} \mathrm{C}$ and then remained unchanged on further heating up to $1400^{\circ} \mathrm{C}$.

$\mathrm{Mg}_{2} \mathrm{Si}$ powder was heated at a temperature between $600^{\circ} \mathrm{C}$ and $1600^{\circ} \mathrm{C}$ for $1 \mathrm{~h}$ in $\mathrm{N}_{2}$ atmosphere. The crystalline phases of the heat-treated powders were examined using XRD. Typical X-ray diffraction patterns are shown in Fig. 4; each sample powder was heated at the desired temperature for $1 \mathrm{~h}$. The crystalline phases at $750^{\circ} \mathrm{C}$ were $\mathrm{Mg}_{2} \mathrm{Si}$, Si and $\mathrm{Mg}_{3} \mathrm{~N}_{2}$. When the temperature was raised up to $900^{\circ} \mathrm{C}$, the crystalline phases were $\mathrm{Mg}_{2} \mathrm{Si}, \mathrm{MgSiN}_{2}$ and Si. Only $\mathrm{MgSiN}_{2}$ was found at $1400^{\circ} \mathrm{C}$. On further heating up to $1600^{\circ} \mathrm{C}$, however, $\alpha-\mathrm{Si}_{3} \mathrm{~N}_{4}$ and $\beta-\mathrm{Si}_{3} \mathrm{~N}_{4}$ were present.

The phase changes during the nitridation of $\mathrm{Mg}_{2} \mathrm{Si}$ were checked on the basis of the characteristic reflection intensities of the reaction products. Results are shown in Fig. 5. The starting $\mathrm{Mg}_{2} \mathrm{Si}$ decreased with temperature and disappeared at $1000^{\circ} \mathrm{C}$. Si and $\mathrm{Mg}_{3} \mathrm{~N}_{2}$ appeared at $600^{\circ} \mathrm{C}$. Although $\mathrm{Mg}_{3} \mathrm{~N}_{2}$ disappeared at $800^{\circ} \mathrm{C}$, Si was still present in the powder up to $1300^{\circ} \mathrm{C}$. The $\mathrm{MgSiN}_{2}$ formed above $800^{\circ} \mathrm{C}$ and increased with temperature up to $1400^{\circ} \mathrm{C}$; however, it disappeared on further heating. Moreover, $\alpha$ $\mathrm{Si}_{3} \mathrm{~N}_{4}$ and $\beta$-Si ${ }_{3} \mathrm{~N}_{4}$ formed above $1400^{\circ} \mathrm{C}$; they increased with a further increase in temperature.

Since $\mathrm{Mg}_{3} \mathrm{~N}_{2}$ and Si were detected at $600^{\circ} \mathrm{C}, \mathrm{Mg}_{2} \mathrm{Si}$ may react with $\mathrm{N}_{2}$ to form $\mathrm{Mg}_{3} \mathrm{~N}_{2}$ and $\mathrm{Si}$ :

$3 \mathrm{Mg}_{2} \mathrm{Si}+2 \mathrm{~N}_{2} \longrightarrow 2 \mathrm{Mg}_{3} \mathrm{~N}_{2}+3 \mathrm{Si}$

As described before, $\mathrm{MgO}$ forms when $\mathrm{Mg}$ and $\mathrm{Si}$ react with $\mathrm{N}_{2}$ at and above $700^{\circ} \mathrm{C}$. Although no $\mathrm{MgO}$ forms when $\mathrm{Mg}_{2} \mathrm{Si}$ reacts with $\mathrm{N}_{2}$, this phenomenon may be ascribed to the low oxygen content $(0.64 \mathrm{~mol} \%)$ in the $\mathrm{Mg}_{2} \mathrm{Si}$ powder. The exothermic effects at $800-820^{\circ} \mathrm{C}$, accompanying the weight increases, are attributed to the formation of $\mathrm{MgSiN}_{2}$ : $2 \mathrm{Mg}_{3} \mathrm{~N}_{2}+3 \mathrm{Si}+\mathrm{N}_{2}$

$$
\longrightarrow 3 \mathrm{MgSiN}{ }_{2}+\mathrm{Mg}_{3} \mathrm{~N}_{2} \text { (amorphous) }
$$

As Eq. (9) indicates, the reaction among $\mathrm{Mg}_{3} \mathrm{~N}_{2}$ (crystalline phase), $\mathrm{Si}$ and $\mathrm{N}_{2}$ appears to produce $\mathrm{MgSiN}_{2}$ and amor-

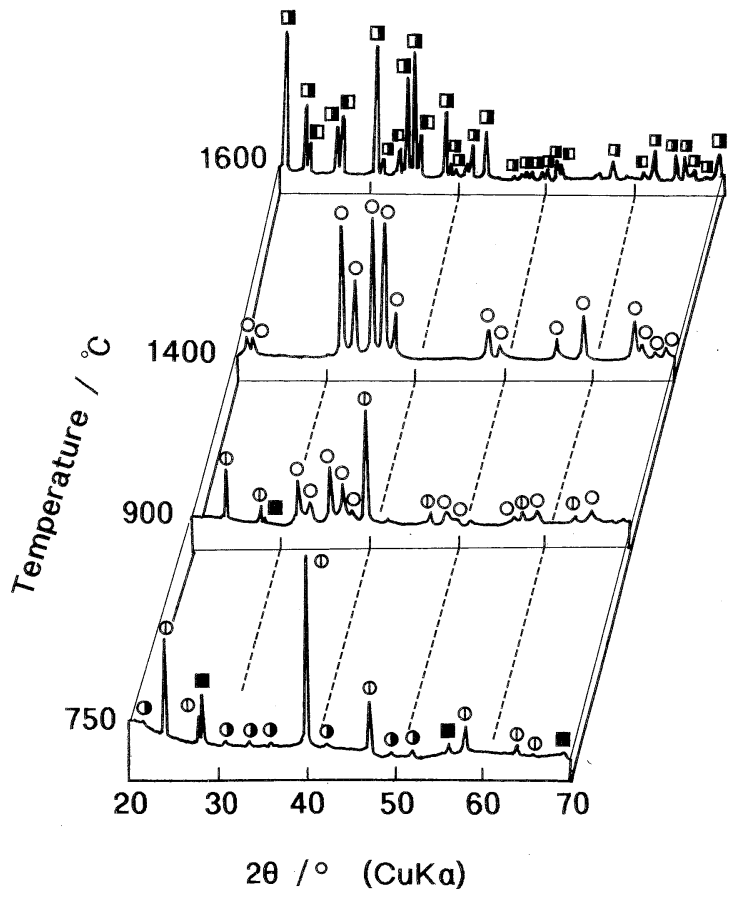

Fig. 4. Typical X-ray diffraction patterns of the $\mathrm{Mg}_{2} \mathrm{Si}$ powders in $\mathrm{N}_{2}$ atmosphere heated up to the desired temperature at the rate of $10^{\circ} \mathrm{C} \cdot \mathrm{min}^{-1}$

Note that the sample was heated at each temperature for $1 \mathrm{~h}$.

(1) $\mathrm{Mg}_{2} \mathrm{Si}, \bigcirc \mathrm{MgSiN}_{2}, \bigcirc \mathrm{Mg}_{3} \mathrm{~N}_{2}, \square \mathrm{Si}$

\ $\alpha-\mathrm{Si}_{3} \mathrm{~N}_{4}, \boldsymbol{\square} \beta-\mathrm{Si}_{3} \mathrm{~N}_{4}$. 


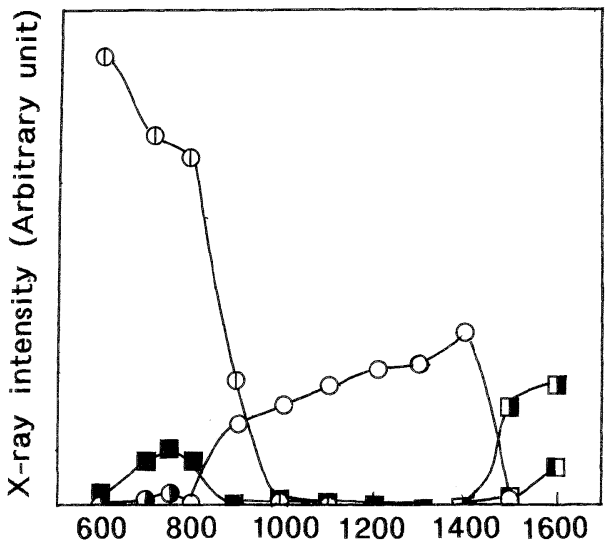

Temperature $/{ }^{\circ} \mathrm{C}$

Fig. 5. Phase changes due to the reaction between $\mathrm{Mg}_{2} \mathrm{Si}$ and $\mathrm{N}_{2}$ with temperature at the heating rate of $10^{\circ} \mathrm{C} \cdot \mathrm{min}^{-1}$.

Note that the sample was heated at each temperature for $1 \mathrm{~h}$.

(1) $\mathrm{Mg}_{2} \mathrm{Si}\left(2 \theta=40.1^{\circ}\right), \bigcirc \mathrm{MgSiN}_{2}\left(2 \theta=36.0^{\circ}\right)$,

- $\mathrm{Mg}_{3} \mathrm{~N}_{2}\left(2 \theta=51.9^{\circ}\right), \mathrm{Si}\left(2 \theta=28.4^{\circ}\right)$,

$\alpha-\mathrm{Si}_{3} \mathrm{~N}_{4}\left(2 \theta=28.4^{\circ}\right), \square \beta-\mathrm{Si}_{3} \mathrm{~N}_{4}\left(2 \theta=30.9^{\circ}\right)$.

phous materials in the $\mathrm{Mg}-\mathrm{N}$ system or nominal composition of $\mathrm{Mg}_{3} \mathrm{~N}_{2}$. Although we predicted that the porous particles might form after an exothermic effect at $800-820^{\circ} \mathrm{C}$, SEM observation showed that the surfaces of the particles were smooth.

The appreciable weight loss at temperatures exceeding $820^{\circ} \mathrm{C}$ up to $1320^{\circ} \mathrm{C}$, accompanying the endothermic effect, corresponds to the evaporation and decomposition of $\mathrm{Mg}_{3} \mathrm{~N}_{2}$ (decomposition temperature: $\sim 1300^{\circ} \mathrm{C}$ ) : ${ }^{12}$ )

$\mathrm{Mg}_{3} \mathrm{~N}_{2} \longrightarrow 3 \mathrm{Mg} \uparrow+\mathrm{N}_{2} \uparrow$

Only $\mathrm{MgSiN}_{2}$ is present in the sample heated at $1400^{\circ} \mathrm{C}$. Since $\mathrm{MgSiN}_{2}$ disappeared to form $\alpha$ - and $\beta-\mathrm{Si}_{3} \mathrm{~N}_{4}$ above $1400^{\circ} \mathrm{C}, \mathrm{MgSiN}_{2}$ is decomposed to form $\mathrm{Si}_{3} \mathrm{~N}_{4}, \mathrm{Mg}$ (vapor) and $\mathrm{N}_{2}$ (vapor) as follows:

$$
3 \mathrm{MgSiN} \mathrm{N}_{2} \longrightarrow \mathrm{Si}_{3} \mathrm{~N}_{4}+3 \mathrm{Mg} \uparrow+\mathrm{N}_{2} \uparrow
$$

Although $\alpha$ - and $\beta$-Si ${ }_{3} \mathrm{~N}_{4}$ were detected from the powder, $\beta$ $\mathrm{Si}_{3} \mathrm{~N}_{4}$ may be more stable than $\alpha-\mathrm{Si}_{3} \mathrm{~N}_{4} \cdot{ }^{13)}$

The above results indicate that the heat-resistant temperature of $\mathrm{MgSiN}_{2}$ appears to be $\sim 1400^{\circ} \mathrm{C}$ and that $\mathrm{MgSiN} \mathrm{N}_{2}$ decomposes into $\alpha-\mathrm{Si}_{3} \mathrm{~N}_{4}$ and $\beta$ - $\mathrm{Si}_{3} \mathrm{~N}_{4}$ at temperatures exceeding $1400^{\circ} \mathrm{C}$.

3.2 Evaluation of some properties of the resulting powder

Since the excellent crystalline $\mathrm{MgSiN}_{2}$ was obtained by nitriding the $\mathrm{Mg}_{2} \mathrm{Si}$ at $1400^{\circ} \mathrm{C}$ for $1 \mathrm{~h}$, some properties of this powder are examined in this section.

3.2.1 Crystallographic evaluation

Table 1 shows the typical chemical composition of this powder. The $\mathrm{Mg}$ and $\mathrm{Si}$ contents were almost in accord with the stoichiometric contents. The content of oxygen

Table 1. Quantitative Analysis of the Synthesized Compounds

\begin{tabular}{|c|c|c|c|c|}
\hline & Mg & $\mathbf{S i}$ & $\mathbf{N}$ & o \\
\hline & $\mathrm{mol} \%$ & $\mathrm{~mol} \%$ & $\mathrm{~mol} \%$ & mol\% \\
\hline $\begin{array}{l}\text { Present study } \\
\left(1400^{\circ} \mathrm{C}, 1 \mathrm{~h}\right)\end{array}$ & 25.20 & 25.55 & 48.49 & 0.76 \\
\hline Groen et al." & 25.49 & 24.63 & 45.12 & 4.76 \\
\hline Hintzen et al. $\left.{ }^{4}\right)$ & -a) & -a) & 44.28 & 5.93 \\
\hline Theoretical & 25.00 & 25.00 & 50.00 & - \\
\hline
\end{tabular}

a) Mg and Si contents were not listed in the paper. was $0.76 \mathrm{~mol} \%$; it was lower than the content reported by Groen et al. $(4.76 \mathrm{~mol} \%)^{3)}$ and that by Hintzen et al. (5.93 $\mathrm{mol} \%)^{4)}$. Moreover, the lattice parameters of $\mathrm{MgSiN}_{2}$ determined by X-ray diffractometry were $a=0.5276 \mathrm{~nm}$, $b=0.6453 \mathrm{~nm}$ and $c=0.4984 \mathrm{~nm}$; the lattice volume was $169.68 \times 10^{-3} \mathrm{~nm}^{3}$. These values are almost in accord with those reported previously, ${ }^{3), 4), 14)}$ which indicates that most of the oxygen may not be solid-soluted into the $\mathrm{MgSiN}_{2}$ lattice. The theoretical density calculated on the basis of the lattice parameters and lattice volume is estimated to be $3.148 \mathrm{~g} \cdot \mathrm{cm}^{-3}$.

We furthermore examined the binding energy of $\mathrm{Si}(2 \mathrm{p})$ by XPS to check for the presence of oxygen; the data were compared with those reported by the previous researchers. ${ }^{15), 16)}$ Typical results are shown in Fig. 6. The $\mathrm{Si}-\mathrm{Si}$ binding energy appeared at $99.4 \mathrm{eV}$; the $\mathrm{Si}-\mathrm{N}$ binding energy appeared at $101.3 \mathrm{eV}$; the $\mathrm{Si}-\mathrm{O}$ binding energy appeared at $102.8 \mathrm{eV}$.

The detection of Si-O binding by XPS indicates that the silicon oxide $\left(\mathrm{SiO}_{2}\right)$ and/or silicon oxynitrides $\left(\mathrm{Si}_{2} \mathrm{~N}_{2} \mathrm{O}\right)$ may be present on and near the surfaces of $\mathrm{MgSiN}_{2}$ particles. ${ }^{3)}$ According to the EDX analysis, $0.76 \mathrm{~mol} \%$ of oxygen are included in the powder. Taking the XPS and EDX results into account, most of the oxygen seem to be present on and near the surfaces of the particles.

\subsubsection{Powder properties}

The color of the $\mathrm{MgSiN}_{2}$ powder was white. The specific surface area of this powder was $3.6 \mathrm{~m}^{2} \cdot \mathrm{g}^{-1}$, while the true density was $3.102 \mathrm{~g} \cdot \mathrm{cm}^{-3}$. The primary particle size calculated on the basis of the specific surface area was 0.54 $\mu \mathrm{m}$, whereas the crystallite size (322) of $\mathrm{MgSiN}_{2}$ calculated on the basis of X-ray diffractometry was $42 \mathrm{~nm}$ $(0.042 \mu \mathrm{m})$.

A typical TEM micrograph of this powder is shown in Fig. 7, together with the electron diffraction pattern. The powder was composed of the particles with the sizes of $\sim 0.5 \mu \mathrm{m}$. The electron diffraction pattern had the spots, reflecting the orthorhombic structure of $\mathrm{MgSiN}_{2}$.

The color of the resulting powder is white as reported by Groen et al. ${ }^{3)}$ The true density $\left(3.102 \mathrm{~g} \cdot \mathrm{cm}^{-3}\right)$ is almost in accord with the theoretical density $\left(3.148 \mathrm{~g} \cdot \mathrm{cm}^{-3}\right)$. Moreover, the particle sizes $(\sim 0.5 \mu \mathrm{m})$ observed by HRTEM agree well with the primary particle size $(0.54 \mu \mathrm{m})$ calculated from the specific surface area. These particles are, therefore, regarded as primary particles. The primary particles appear to be polycrystals, because the primary particle size $(0.54 \mu \mathrm{m})$ is over ten times as large as the crystallite size $(0.042 \mu \mathrm{m})$

3.2.3 Resistivity to the oxidation and hydration

The application of $\mathrm{MgSiN}_{2}$ to the engineering materials

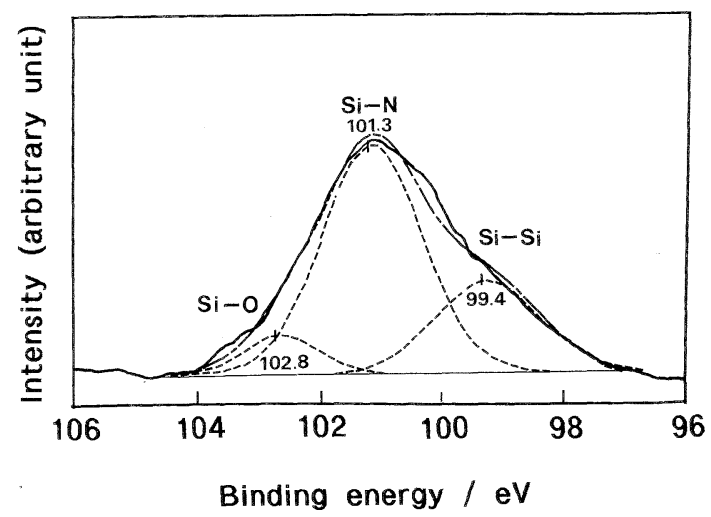

Fig. 6. XPS Si (2p) spectrum of the $\mathrm{Mg}_{2} \mathrm{SiN}_{2}$ powder obtained by nitriding the $\mathrm{Mg}_{2} \mathrm{Si}$ at $1400^{\circ} \mathrm{C}$ for $1 \mathrm{~h}$. 


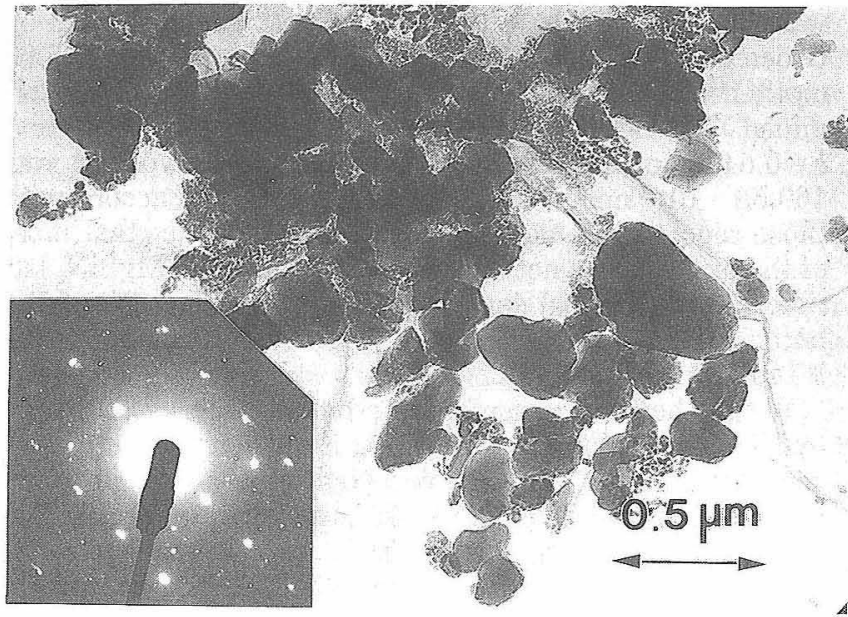

Fig. 7. HR-TEM micrograph and electron diffraction pattern of the $\mathrm{MgSiN}_{2}$ powder obtained by nitriding the $\mathrm{Mg}_{2} \mathrm{Si}$ at $1400^{\circ} \mathrm{C}$ for 1h.

and/or high-thermal conducting materials requires an ability to resist oxidation and/or hydration. Thus the resistivity to the oxidation and hydration was examined in this section.

First, DTA was conducted to examine the resistivity to the oxidation of $\mathrm{MgSiN}_{2}$. Results are shown in Fig. 8. DTA curve showed that the exothermic effects started at $710^{\circ} \mathrm{C}$ and $1270^{\circ} \mathrm{C}$. Although little changes in sample weight were observed below $830^{\circ} \mathrm{C}$, the sample weight increased with a further increase in temperature.

On the basis of the above DTA-TG results, the crystalline phases of the heat-treated powders were examined using the XRD. Typical X-ray diffraction patterns of the heat-treated powders are shown in Fig. 9, together with the pattern at room temperature. Although only $\mathrm{MgSiN}_{2}$ was present at room temperature, $\mathrm{MgO}$ and $\mathrm{Mg}_{2} \mathrm{SiO}_{4}$ (trace) formed at $1040^{\circ} \mathrm{C}$, together with $\mathrm{MgSiN}_{2}$. When the temperature was raised up to $1210^{\circ} \mathrm{C}, \mathrm{Mg}_{2} \mathrm{SiO}_{4}, \mathrm{MgO}$ and $\mathrm{MgSiN}_{2}$ (trace) were present. On further heating up to $1400^{\circ} \mathrm{C}$, the crystalline phases were $\mathrm{Mg}_{2} \mathrm{SiO}_{4}$ and $\mathrm{MgSiO}_{3}$ (protoenstatite).

Since $\mathrm{MgSiN}, \mathrm{MgO}$ and $\mathrm{Mg}_{2} \mathrm{SiO}_{4}$ were detected at $1040^{\circ} \mathrm{C}$, the first exothermic effect which started at $710^{\circ} \mathrm{C}$ may be attributed to ( $\mathrm{i}$ ) the thermal decomposition of $\mathrm{MgSiN}_{2}$ and (ii) the formation of $\mathrm{MgSiO}_{3}$ (protoenstatite):

$$
\begin{aligned}
& \underset{2 \mathrm{MgSiN}}{2}+3 \mathrm{O}_{2} \\
& \stackrel{2 \mathrm{MgO}}{\longrightarrow}+2 \mathrm{SiO}_{2} \text { (amorphous) }+2 \mathrm{~N}_{2} \uparrow \\
& \underset{2 \mathrm{MgO}}{\longrightarrow}+2 \mathrm{SiO}_{2} \\
& \stackrel{\mathrm{Mg}_{2} \mathrm{SiO}_{4}}{ }+\mathrm{SiO}_{2} \text { (amorphous) }
\end{aligned}
$$

Regardless of the gradual exothermic effect, however, little weight changes occurred in the range of $710^{\circ} \mathrm{C}$ to $830^{\circ} \mathrm{C}$, which suggests that the thin $\mathrm{MgO}$ and $\mathrm{SiO}_{2}$ (amorphous) layers formed on the surfaces of the particles at the initial stage prevent from a further oxidation inside the particles.

Since $\mathrm{Mg}_{2} \mathrm{SiO}_{4}$ and $\mathrm{MgSiO}_{3}$ (protoenstatite) were detected at $1400^{\circ} \mathrm{C}$, the solid state reaction in the range of $1270^{\circ} \mathrm{C}$ to $1400^{\circ} \mathrm{C}$ may be expressed as follows:

$\mathrm{Mg}_{2} \mathrm{SiO}_{4}+\mathrm{SiO}_{2}$ (amorphous) $\longrightarrow 2 \mathrm{MgSiO}_{3}$

Contrary to the prediction of no weight increases, according to Eq. (14), the sample weight increases in this temperature range. The exothermic effect which started at $1270^{\circ} \mathrm{C}$ appears to occur due to the rapid oxidation of the residual $\mathrm{MgSiN}_{2}$, initiating from the crack formation of the oxide films on the particles.

It is concluded that $\mathrm{MgSiN}_{2}$ may be stable up to $\sim 830^{\circ} \mathrm{C}$, because no appreciable weight changes were observed below this temperature.

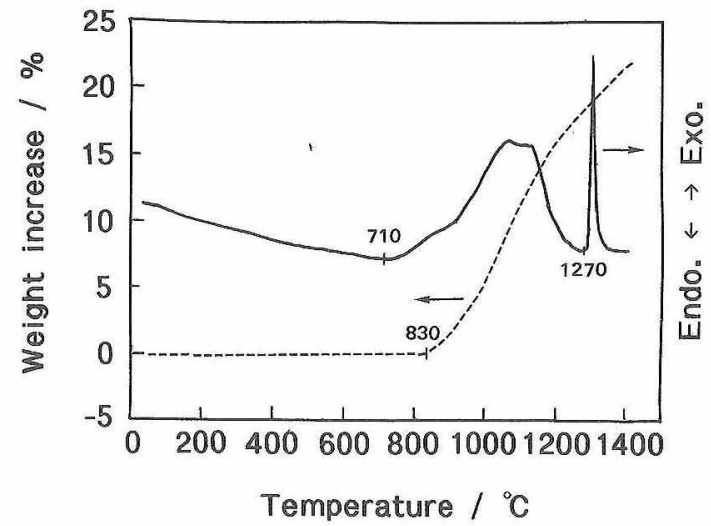

Fig. 8. DTA-TG curves of $\mathrm{MgSiN}_{2}$ powder in air at the heating rate of $10^{\circ} \mathrm{C} \cdot \mathrm{min}^{-1}$.

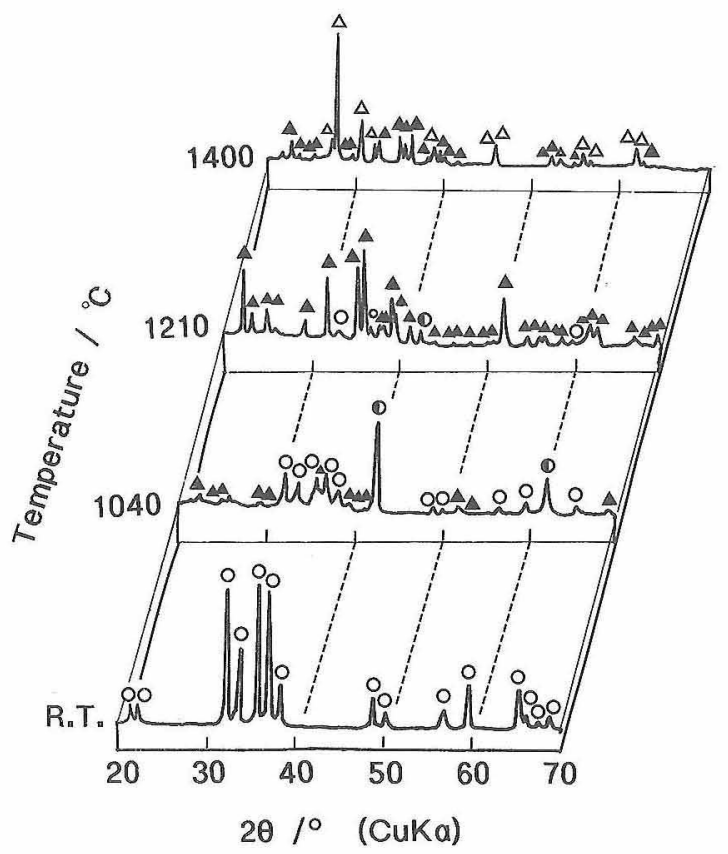

Fig. 9. Typical X-ray diffraction patterns of the $\mathrm{MgSiN}_{2}$ powders heated up to the desired temperature in air at the heating rate of $10^{\circ} \mathrm{C} \cdot \mathrm{min}^{-1}$.

$\bigcirc \mathrm{MgSiN}_{2}, \mathrm{MgO}, \triangle \mathrm{Mg}_{2} \mathrm{SiO}_{4}$,

$\triangle \mathrm{MgSiO}_{3}$ (protoenstatite).

The water-proof test was conducted by immersing the powder in boiling water. The sample weight increased up to 21.06 mass\% after the water-proof test. Although the XRD data were omitted in this paper, no other crystalline phases were observed after the water-proof test; however, the reflection intensities of $\mathrm{MgSiN}_{2}$ were slightly lowered after the water-proof test.

An increase in sample weight indicates that the magnesium and silicon hydroxides may be formed on and near the surfaces of the particles. Regardless of the formation of such hydroxides, however, it is noteworthy that the crystal structure of $\mathrm{MgSiN}_{2}$ is still maintained even after the "severe" water-proof test.

\section{Conclusion}

The synthesis conditions of magnesium silicon nitride $\left(\mathrm{MgSiN}_{2}\right)$ were examined by the nitridation of the powders in the $\mathrm{Mg}$-Si system. The results obtained can be summarized as follows: 
(1) The mixed $\mathrm{Mg}$ and Si powders with $\mathrm{Mg} / \mathrm{Si}$ ratio of 1.0 (stoichiometric ratio of $\mathrm{MgSiN}_{2}$ ) was heated up to $1400^{\circ} \mathrm{C}$ in nitrogen $\left(\mathrm{N}_{2}\right)$ atmosphere. The single $\mathrm{MgSiN}_{2}$ phase could not be obtained by this technique, because some $\mathrm{Mg}$ were evaporated during heating.

(2) The $\mathrm{Mg}_{2} \mathrm{Si}$ powder was heated at a temperature between $600^{\circ} \mathrm{C}$ and $1600^{\circ} \mathrm{C}$ for $1 \mathrm{~h}$ in $\mathrm{N}_{2}$ atmosphere. The single $\mathrm{MgSiN}_{2}$ phase was obtained by nitriding the $\mathrm{Mg}_{2} \mathrm{Si}$ at $1400^{\circ} \mathrm{C}$ for $1 \mathrm{~h}$. The chemical composition of the resulting powder was almost in accord with the stoichiometric composition; the content of the oxygen was as low as 0.76 $\mathrm{mol} \%$.

(3) The $\mathrm{MgSiN}_{2}$ powder was composed of agglomerates with the sizes of $\sim 5 \mu \mathrm{m}$ in which the primary particles with the sizes of $\sim 0.5 \mu \mathrm{m}$ were adhered to one another. The oxidation-resistant temperature of the $\mathrm{MgSiN}_{2}$ powder was estimated to be $\sim 830^{\circ} \mathrm{C}$. The $\mathrm{MgSiN}_{2}$ powder has good resistivity to hydration.

Acknowledgments The authors wish to express their thanks to Professors Dr. Y. Toda and Dr. K. Hashimoto of Chiba Institute of Technology for taking the high-resolution TEM micrographs and for performing electron diffraction analysis, to Dr. A. Tsuge of National Industrial Research Institute of Nagoya for the oxygen and nitrogen determination, and to Mr. K. Tanaka of Sophia University for XPS analysis.

\section{References}

1) G. A. Slack, R. A. Tanzilli, R. O. Pohl and W. Vandersande, J. Phys. Chem. Solids, 47, 641-47 (1987).

2) G. A. Slack, J. Phys. Chem. Solids, 34, 321-35 (1973).
3) W. A. Groen, M. J. Kraan and G. de With, J. Eur. Ceram. Soc., 12, 413-20 (1993).

4) H. T. Hintzen, P. Swaanen, R. Metselaar, W. A. Groen and M. J. Kraan, J. Mater. Sci. Lett., 13, 1314-16 (1994).

5) J. David and J. Lang, Compt. Rend. Acad. Sci. Paris, 261, 1005-07 (1965)

6) T. Murata, K. Itatani, F. S. Howell, A. Kishioka and M. Kinoshita, J. Am. Ceram. Soc., 76, 2909-11 (1993).

7) Powder Diffraction File Card No. 35-773, JCPDS International Center for Diffraction Data, Newtown Square, PA (1985).

8) Powder Diffraction File Card No. 35-778, JCPDS International Center for Diffraction Data, Newtown Square, PA (1985).

9) Powder Diffraction File Card No. 25-530, JCPDS International Center for Diffraction Data, Newtown Square, PA (1975).

10) "Metals Handbook Desk Edition," Ed. by H. E. Boyer and T L. Gall, American Society for Metals, Metals Park, OH, USA (1985) p. 14.7, 14.10.

11) Gmelins Handbuch der Anorganischen Chemie, Magnesium, Teil A, Ed. by Gmelin-Institute, Weinheim/Bergsrasse, Germany (1952) p. 222.

12) "Kagaku Daijiten," Vol. 5, Compiled by the Committee of Kagaku Daijiten, Kyoritsu Shuppan, Tokyo, Japan (1979) p. 887.

13) P. Longland and A. J. Moulson, J. Mater. Sci., 13, 2279-80 (1978).

14) S. Wild, P. Grieveson and K. H. Jack, Spec. Ceram., Vol. 5 (1972) pp. 289-97.

15) C. G. Wagner, H. A. Six, W. T. Jansen and J. A. Taylor, Appl. Surf. Sci., 9, 203-13 (1981).

16) J. A. Taylor, Appl. Surf. Sci., 7, 168-84 (1981). 